\title{
Potential applications of waste lignin from the paper and pulp industry in Viet Nam
}

\author{
Thanh Khoa Phung ${ }^{1,2,}{ }^{*}$, Quynh-Thy Song Nguyen ${ }^{3}$, Khanh B. Vu ${ }^{1,2}$, Giang Duy-Le Vo ${ }^{1,2}$, Vinh Ngoc Nguyen ${ }^{2,4}$
}

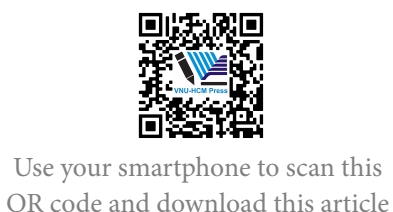

QR code and download this article

\begin{abstract}
The conversion of waste lignin from the paper and pulp industry is a potential process to produce chemicals and materials in the industry. With the development and the demand for the pulp and paper industry, the amount of waste lignin will increase remarkably. In Vietnam, the forest tree for the pulp industry is abundant, and the pulp industry has increased in recent years. In parallel, the government planned to develop the material resource and high-tech factories for this industry. In this work, we summarized the pulp and paper industry in Vietnam, then suggest the potential applications of waste lignin in several valuable products.

Key words: Lignin, paper industry, agriculture, construction, carbon fiber, fuel
\end{abstract}

${ }^{1}$ Department of Chemical Engineering, School of Biotechnology, International University, Ho Chi Minh City, Vietnam

${ }^{2}$ Vietnam National University, Ho Chi Minh City, Vietnam

${ }^{3}$ Industrial Development Center of Southern Vietnam, Ministry of Industry and Trade, 12 Nguyen Thi Minh Khai street, District 1, Ho Chi Minh City, Vietnam

${ }^{4}$ Department of Environmental Engineering, International University, Ho Chi Minh City, Vietnam

\section{Correspondence}

Thanh Khoa Phung, Department of Chemical Engineering, School of Biotechnology, International University, Ho Chi Minh City, Vietnam

Vietnam National University, Ho Chi Minh City, Vietnam

Email: ptkhoa@hcmiu.edu.vn

History

- Received: 2020-08-19

- Accepted: 2020-10-04

- Published: 2020-10-09

DOI : 10.32508/stdj.v23i4.2442

\section{Check for updates}

\section{Copyright}

(c) VNU-HCM Press. This is an openaccess article distributed under the terms of the Creative Commons Attribution 4.0 International license.

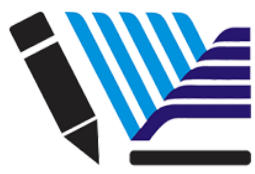

VNU-HCM Press

\section{INTRODUCTION}

Lignin is a by-product of the pulp and paper industry, and it can be considered as a renewable material coming from lignocellulosic feedstock. In the industry, technical lignin can be classified by the lignin production processes (Table 1). The current technology to produce lignin can be classified into sulfurcontaining lignin and sulfur-free lignin technology ${ }^{1}$. Sulfur-containing lignin contains Kraft lignin, sulfite lignin, and hydrolyzed lignin from the Kraft process, lignosulfonates process, and enzymatic hydrolysis process, respectively. While sulfur-free lignin comes from Organosolv and soda processes ${ }^{1}$. The global lignin market size is around USD 954.5 million in 2019 and grows up 2\% each year from 2020 to $2027^{2}$. For the production, global lignin production is around 100 million tonnes/year in 2015 and expected to increase to 225 million tonnes per year in $2030^{1}$. Lignosulphonate is the most global lignin production. Additionally, lignin from the paper and pulp industry has to treat to remove the pollutants before using, and there are several techniques that have been used for the removal and recovery of lignin ${ }^{3}$. The technology for the recovery of lignin carried out on physicochemical and biological methods. The physicochemical methods include coagulation and precipitation, adsorption, membrane technologies, ozonation, and advanced oxidation processes ${ }^{3}$.

Looking at the chemical view, lignins have aromatic backbones ${ }^{4}$, making them an ideal renewable feedstock of aromatic compounds for a range of applications, including automotive brakes, wood panel products, surfactants, phenolic resins, phenolic foams, biodispersants polyurethane foams, and epoxy resins ${ }^{5-10}$. In fact, native lignin is a heterogeneous polymer with the phenylpropane unit (C9-unit) of the p-hydroxyphenyl $(H)$, guaiacyl $(G)$ and syringyl (S) types ${ }^{4,11}$. The $\mathrm{C} 9$ units are linked to form lignin with $\mathrm{C}-\mathrm{O}-\mathrm{C}$ and $\mathrm{C}-\mathrm{C}$ linkages (Figure $\mathbf{1}$ ), and the most abundant linkage of lignin is $\beta$-O-4 linkage ( 45 $65 \%)^{12}$. Based on the structure of lignin, it has many advanced properties such as biodegradability, antiaging to asphalt (in lignin-epoxy resins), antioxidant and UV-protection ${ }^{1}$, super strength (for cement), adhesive binding ${ }^{11}$, good thermal property, watersoluble of lignosulfonates lignin (apply for binders, dispersing agent, surfactant, adhesive and cement additives) ${ }^{13}$. However, lignin is considered as waste and primarily burned for recovering energy, and utilizes only less than $2 \%$ to produce chemical products ${ }^{13,14}$. Even though the application of lignin increases due to the demand for lignin in animal feed and natural products $^{2}$; also, lignin is used in the production of bitumen, biofuels, bio-refinery catalysts, concrete admixtures, adhesives, and binders. The application of lignin will be presented in detail in the next section. In Vietnam, the paper industry is an old industry. Before the 20th century, the paper was made in a manual method. In 1912, the first paper factory was established with a capacity of 4000 tonnes/year in Viet Tri city. After that, several factories were built, and the Bai Bang paper factory was the biggest paper factory with 53,000 tonnes of pulp/year and 55,000 tonnes paper/year ${ }^{17}$. In recent years, the paper industry has 


\begin{tabular}{ccccc}
\hline \multicolumn{2}{l}{ Table 1: Classification of technical lignins ${ }^{15,16}$} & & \\
\hline Lignin type & Scale & Chemistry & Sulphur content & Purity \\
Kraft & Industrial & Alkaline & Low & High \\
Lignosulphonate & Industrial & Acidic & High & Low \\
Organosolv & Industrial/Pilot & Acidic & Free & High \\
Soda & Industrial/Pilot & Alkaline & Free & Moderate \\
Hydrolytic & Industrial/Pilot & Acidic & Low/Free & Moderate \\
\hline
\end{tabular}

increased production capacity. In the period 2016 2019 , paper production increased by around $31 \%$ each year ${ }^{18}$, the production output also increased by $25.7 \%$ annually. Additionally, the consumption and export of paper went up to $12.3 \%$ and $65.1 \%$, respectively ${ }^{18}$. In fact, the total paper consumption and export are estimated at 5.432 million tonnes and 1 million tonnes in 2019 , respectively ${ }^{19}$. In which, Vietnam produced ca. 4.43 million tonnes of pulp and paper in 2019, which was higher than 2018 around $20.6 \%$, based on the data of the Pulp and Paper Associate ${ }^{20}$. Therefore, a large amount of by-product, lignin, will become available to transform into valuable products. In this work, we summarize the pulp and paper industry in Vietnam and suggest the potential applications of waste lignin in Vietnam.

\section{REVIEW}

\section{The pulp and paper industry in Vietnam Materials}

Vietnam is a tropical country and has the mountain account for ca. $40 \%$ of the country's land area. Vietnam has a huge amount of forest and plantation trees for the pulp and paper industry. The main material region is located in the North and Central of Vietnam, while the big pulp and paper factories are located in the South of Vietnam ${ }^{17}$. Therefore, the government decided to plan the regions for the development of paper raw material plants, as shown in Table 2.

With this plan, wood chips - material for pulp and paper - have been increased and become abundant. At present, wood chips are enough for the pulp and paper production in Vietnam and export as well. Additionally, China is the biggest pulp market in the world, and they need around 21.44 million tonnes of pulp/year ${ }^{18}$. China is our neighbor making a reduction in transportation cost. Therefore, it is great to develop material for the pulp and paper industry due to the demand for our own country and export as well. Currently, the export of wood chips has been increased year by year and reached more than USD 1.3 billion per year, as shown in Table 3.

\section{The pulp and paper industries}

Though Vietnam has a huge amount of materials for the pulp and paper industries, the most product produced is packaging paper (82\%) from the waste paper (Figure 2) ${ }^{18}$. In which, we have to import waste paper for the packaging paper production due to the low recovery waste paper $(<40 \%)$ in Vietnam ${ }^{22}$. For the writing paper, the production responses for $55 \%$ of the national demand and it needs to import $45 \%$ of the demand, around 483,000 tonnes/year ${ }^{18}$. It is due to the low-tech factories in Vietnam ${ }^{17}$. Therefore, we need to invest the fund for the development of the hitech pulp and paper industry to increase the value of this industry and reduce the environmental effect.

In order to enhance the national production of pulp and paper, the government planned to invest in the hi-tech pulp and paper industries (Table 4) to increase production capacity and reduce the cost and pollution effect $^{21}$. The investment plan helped to improve the pulp and paper industries of Vietnam and reduce the dependence of importation. The enhancement of this industry also boosts an increase in the plantation industry, making the increase in the economy in rural areas. Additionally, the spread of the pulp and paper factories near the area of materials reduces the transportation cost of materials and products as well.

Interestingly, several companies recently invested in the high-tech pulp/paper factories in Vietnam to upgrade the paper sector. Indeed, Lee \& Man Vietnam invested USD 650 million to build a paper factory with a production capacity of 420,000 tonnes/year in Hau Giang province ${ }^{23}$. This factory mainly produces packaging paper from more than $95 \%$ of wastepaper. However, this factory applies high technology to produce high-quality paper from waste paper and reduces water pollution. In parallel, the government also encourages investment in the pulp industry and allows only the high technology plant to avoid any risk of the environment. The joint-stock company between Thai Binh Xanh and Poyry declared to invest VND 11,650 billion in a pulp factory in Quang Tri province ${ }^{24}$. This pulp factory planned to produce 


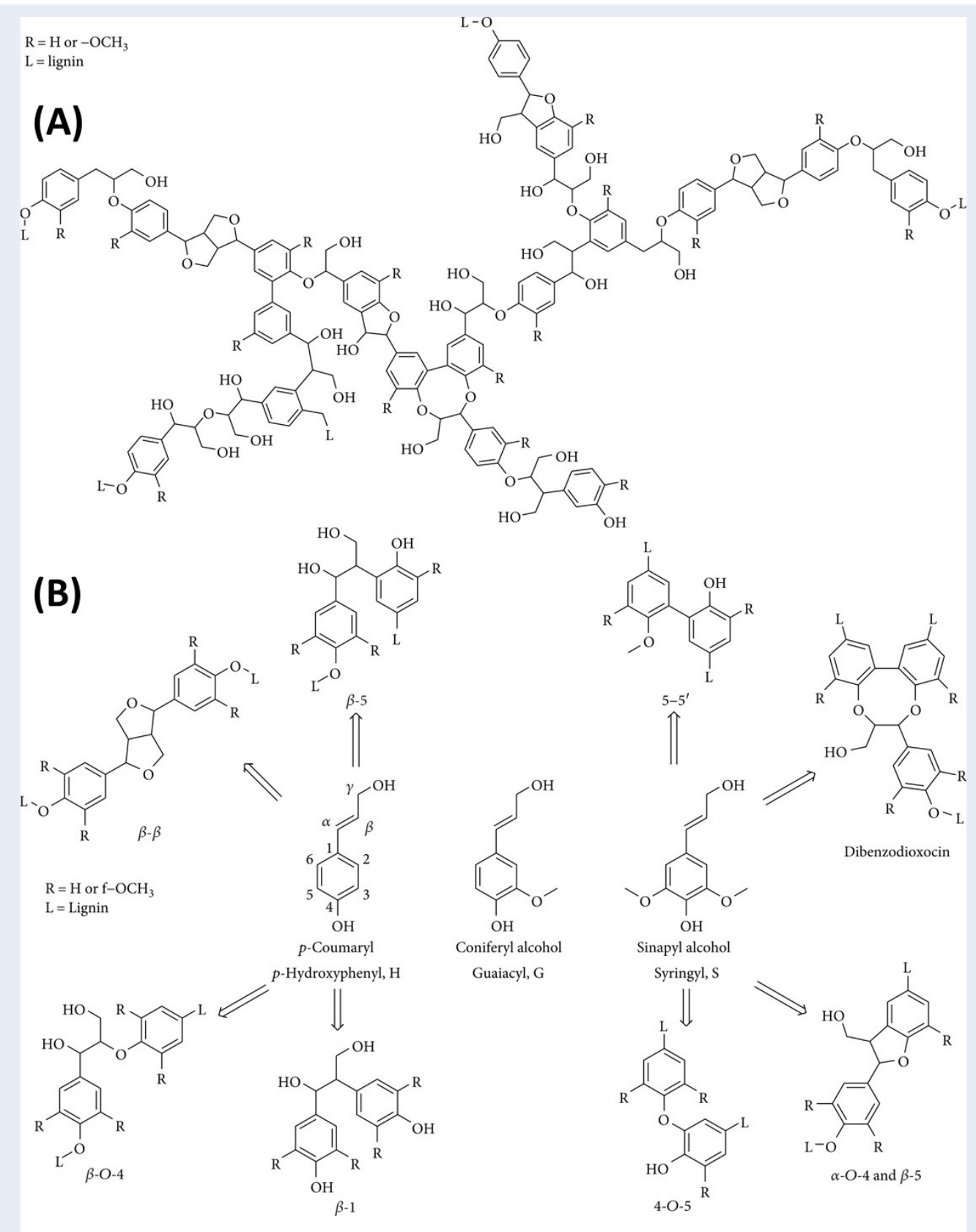

Figure 1: (a) A typical structural model of lignin; and (b) the linkages in lignin. Reproduced from Open-access ref. $^{12}$ 
Table 2: Regions and areas for the development of paper raw material plants ${ }^{21}$

\begin{tabular}{|c|c|c|c|c|c|c|c|c|}
\hline \multirow[t]{2}{*}{ Period } & \multicolumn{8}{|c|}{ Region (Unit: ha) } \\
\hline & Northwest & Northeast & $\begin{array}{c}\text { Red } \\
\text { River } \\
\text { Delta }\end{array}$ & $\begin{array}{l}\text { North } \\
\text { Central }\end{array}$ & $\begin{array}{l}\text { South } \\
\text { Central } \\
\text { Coast }\end{array}$ & $\begin{array}{l}\text { North } \\
\text { Central } \\
\text { High- } \\
\text { lands }\end{array}$ & $\begin{array}{l}\text { South } \\
\text { Central } \\
\text { High- } \\
\text { lands }\end{array}$ & $\begin{array}{l}\text { Mekong } \\
\text { River } \\
\text { Delta }\end{array}$ \\
\hline \multicolumn{9}{|l|}{ 2011-2015 } \\
\hline Forest area in 2015 & 123,500 & 104,550 & 142,800 & 136,992 & 159,501 & 86,781 & 75,950 & 42,100 \\
\hline $\begin{array}{l}\text { Afforestation after } \\
\text { exploitation }\end{array}$ & 51,000 & 63,500 & 82,500 & 63,000 & 80,000 & 32,500 & 38,500 & 34,500 \\
\hline Planting new forests & 61,100 & 27,500 & 34,800 & 43,500 & 64,000 & 47,500 & 29,500 & 800 \\
\hline \multicolumn{9}{|l|}{$2016-2020$} \\
\hline Forest area in 2020 & 145,500 & 110,550 & 164,300 & 157,492 & 173,001 & 104,781 & 85,450 & 42,100 \\
\hline $\begin{array}{l}\text { Afforestation after } \\
\text { exploitation }\end{array}$ & 121,247 & 92,122 & 136,917 & 131,243 & 144,168 & 72,318 & 71,208 & 35,083 \\
\hline Planting new forests & 22,000 & 6,500 & 21,500 & 20,500 & 13,500 & 18,000 & 9,500 & 0 \\
\hline \multicolumn{9}{|l|}{$2021-2025$} \\
\hline Forest area in 2025 & 145,500 & 110,550 & 164,300 & 157,492 & 173,001 & 104,781 & 85,450 & 42,100 \\
\hline $\begin{array}{l}\text { Afforestation after } \\
\text { exploitation }\end{array}$ & 132,269 & 100,496 & 149,364 & 143,175 & 157,274 & 95,255 & 77,682 & 38,273 \\
\hline
\end{tabular}

Table 3: Value of Vietnam's woodchip export till the end of April 201922,23

\begin{tabular}{ccc}
\hline Year & Quantity (dry tons) & Value (USD) \\
2010 & $3,996,381$ & $437,021,153$ \\
2011 & $5,179,093$ & $761,871,879$ \\
2012 & $5,820,885$ & $796,351,503$ \\
2013 & $7,063,461$ & $983,390,245$ \\
2014 & $6,971,740$ & $958,044,609$ \\
2015 & $8,062,563$ & $1,166,400,705$ \\
2016 & $7,221,613$ & $986,850,338$ \\
2017 & $8,201,298$ & $1,072,656,296$ \\
2018 & $10,375,720$ & $1,340,083,064$ \\
\hline
\end{tabular}

300,000 - 700,000 tonnes/year with friendly environmental technology. Those investments along with other investments from Vietnam and foreign companies, will boost the pulp and paper industry in Vietnam, making an increase in the number of laborers, economy, and the following industry as well, such as the industry of lignin, by-product from the pulp and paper industry.

\section{The applications of lignin}

As mentioned, lignin is considered as a waste, but its application is rising in recent years. Indeed, lignin has a broad application in many fields, and it has many specific benefits in each field. The summary of the lignin application is illustrated in Table 5.

Besides those applications with the technologies developed by Borregaard, several technologies have been developed focusing on the transformation of 


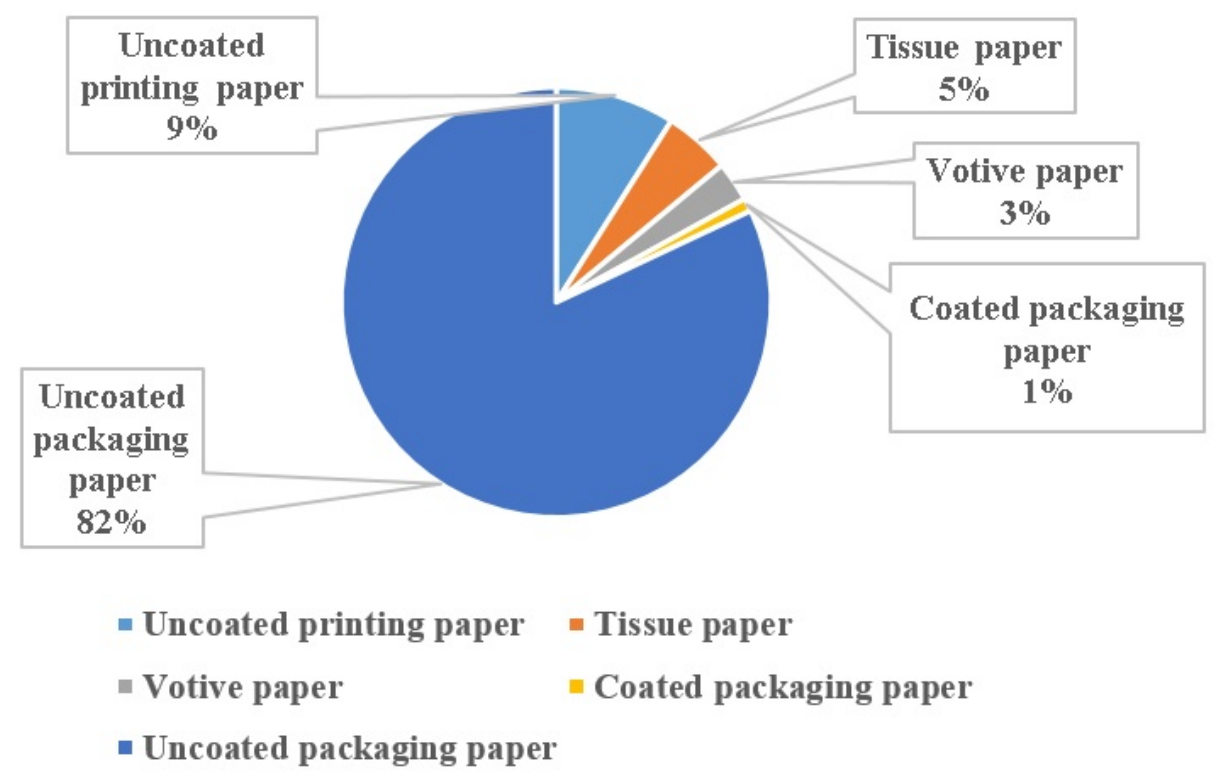

Figure 2: The percentage of paper products in Vietnam ${ }^{18}$

lignin by chemical processes. The new technologies focus on lignin depolymerization (hydrogenolysis, pyrolysis, oxidation, hydrolysis, and gasification), functionalization of hydroxyl groups (alkylation, phenolation, urethanization, and etherification), synthesis of chemically active sites (hydroxyalkylation, amination, nitration, and sulfonation), and production of lignin graft copolymers ${ }^{1}$. Moreover, there are some technologies showing novel applications of lignin in the production of lignin-based carbon fibers, BTX, phenol, oxidized products, energy storage devices, nanocomposites, drug delivery systems, tissue engineering, filtration, and heavy metal capturing devices $^{1}$. Figure 3 shows several potential conversions of lignin into useful products; it can be converted into phenolic compounds applying many industries or copolymerize to form a copolymer in the plastic industry.

\section{The potential applications of lignin in Viet- nam}

Based on the current industry in Vietnam and the demand for the industry, lignin has many potential applications in Vietnam. These potential applications rely on the current condition in Vietnam. Vietnam is in the process of transforming from an agricultural to industrial country; therefore, the demand for both agriculture and industry has been increased in recent years. The increase of industry boosts the de- velopment of the economy and the demand for development of house and building, materials as well as bulk chemicals and fuels. There are several potential applications of lignin such as dispersants, paper sizing, industrial cleaners and water treatment, concrete admixtures, unbaked bricks, and plant nutrition (Figure 4). Those products have many advantages, e.g., the advantages of dispersants are milling economy, a wide range of heat stability, controlled fiber staining, no azo reduction, lower paste viscosity in the formulation, improved cost/performance after standardization of dye strength, and environmentally friendly ${ }^{29}$. While the advantages of plant nutrition are Improving formulations and plant nutrition, stable solutions, custom formulations ${ }^{30}$; of concrete admixtures are improved strength and durability of the cured concrete, reduced formulation cost, increased workability of the concrete mix, cost effective water reducers ${ }^{31}$; of Industrial Cleaners and water treatment are cost-effective additives for industrial cleaning to disperse dirt particles, in water treatment formulations to reduce the fouling of cooling water as well as a low-cost conditioning agent for boiler water sludges, enhance the metal cleaning and water treatment abilities of other components typically present in these types of formulations and are compatible with sodium citrate, gluconates, EDTA, NTA, and triethanolamine ${ }^{32}$; of papersizing provide a simple and ready to use green solution for increasing the 


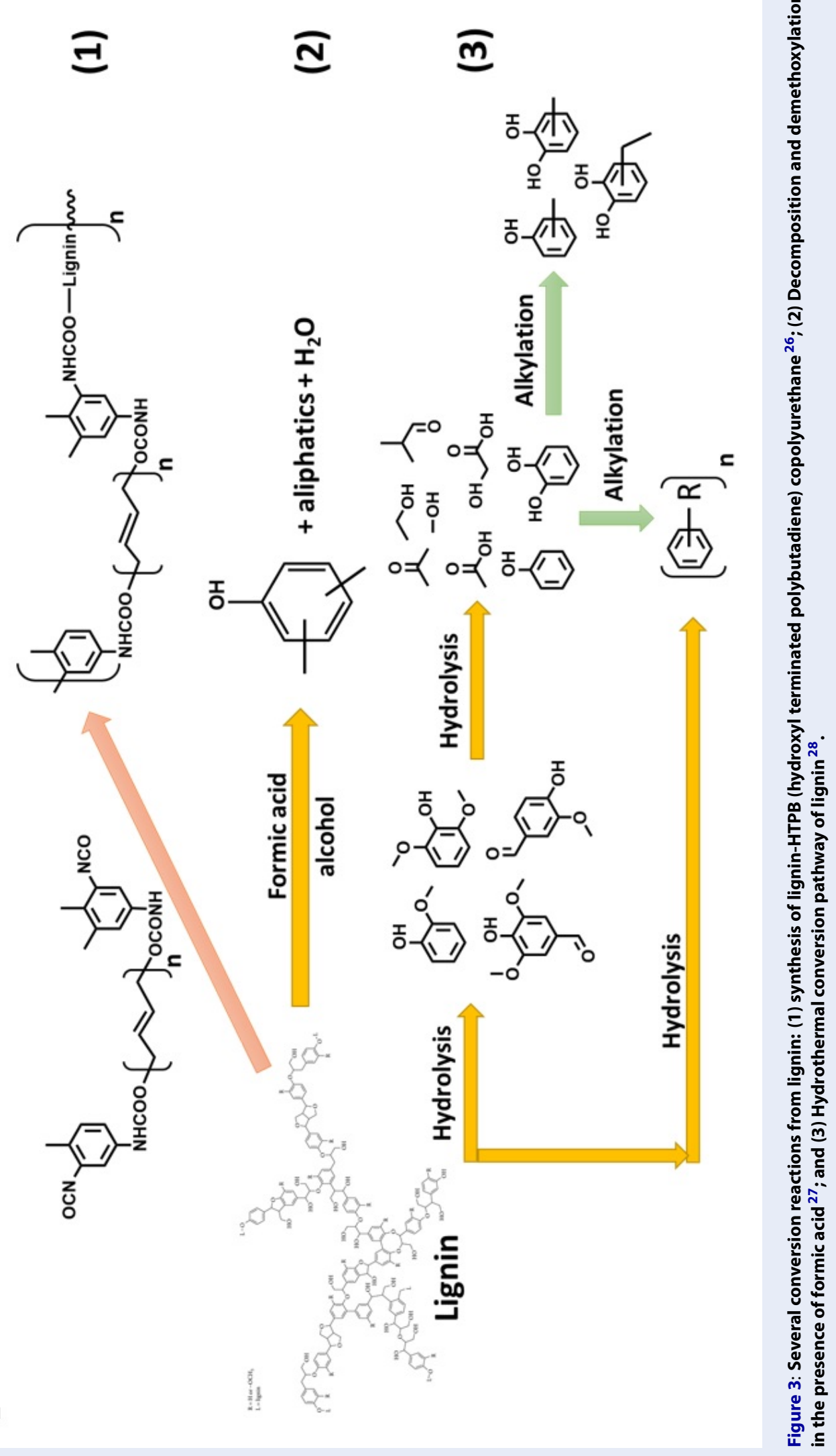




\begin{tabular}{|c|c|c|c|c|c|}
\hline \multirow[t]{2}{*}{ Seq. } & \multirow[t]{2}{*}{ Company/Factory } & \multirow[t]{2}{*}{ Region } & \multicolumn{2}{|c|}{$\begin{array}{l}\text { Production capacity } \\
\text { (tons/year) }\end{array}$} & \multirow[t]{2}{*}{ Period } \\
\hline & & & Pulp & Paper & \\
\hline 1 & Vietnam pulp and paper company & Phu Tho & - & 150,000 & 2011-2015 \\
\hline 2 & Phuong Nam pulp factory & Long An & 100,000 & - & $2012-2020$ \\
\hline \multirow[t]{2}{*}{3} & An Hoa company & Tuyen Quang & 130,000 & - & Produced \\
\hline & & & & 140,000 & 2011-2015 \\
\hline 4 & Pulp factory & Southern & & 650,000 & 2011-2015 \\
\hline 5 & Pulp and paper factory & North Central & 100,000 & 180,000 & 2011-2015 \\
\hline 6 & Pulp factory & South Central Coast & 250,000 & - & $2012-2015$ \\
\hline 7 & Pulp factory & Red River Delta & 50,000 & - & $2010-2015$ \\
\hline 8 & Paper factory & Market area & & $1,080,000$ & 2011-2015 \\
\hline 9 & Pulp and paper factory & Central Highlands & 130,000 & 200,000 & $2010-2020$ \\
\hline 10 & Pulp and paper factory & South Central Coast & 130,000 & 400,000 & $2010-2020$ \\
\hline 11 & Pulp and paper factory & Mekong River Delta & 330,000 & 420,000 & 2011-2020 \\
\hline 12 & Pulp and paper factory & Northeast & 250,000 & 200,000 & $2016-2020$ \\
\hline 13 & Pulp and paper factory & North Central & 150,000 & 200,000 & $2016-2020$ \\
\hline 14 & Paper factory & Market area & - & $1,130,000$ & $2016-2020$ \\
\hline 15 & Paper factory & North Central & - & 200,000 & 2021-2025 \\
\hline 16 & Expanding pulp and paper factory & Red River Delta & 300,000 & 200,000 & 2021-2025 \\
\hline 17 & Pulp and paper factory & South Central Coast & 300,000 & 250,000 & 2021-2025 \\
\hline 18 & Expanding pulp and paper factory & Central Highlands & 130,000 & 200,000 & 2021-2025 \\
\hline 19 & Other projects & Market area & & $2,855,000$ & 2021-2025 \\
\hline Total & & & $2,350,000$ & $8,455,000$ & \\
\hline
\end{tabular}

strength of recycled based corrugated mediums on size-film press or spray sizer, increased CMT, SCT, RCT, reduced energy consumption and steam energy savings, improved runability, enhanced optical properties $^{33}$; and of unbaked bricks are achieving the standard in the compressive and yield strength, low-cost material, reducing the environment effect ${ }^{34}$.

Among the potential products, concrete admixtures, unbaked bricks, plant nutrition, carbon fiber, and bulk chemicals are the most potential products in Vietnam. In fact, the concrete mixtures, unbaked bricks, and plant nutrition are the most viable applications of lignin in Vietnam due to the high demand for raw materials in these industries as well as easy production processes. Moreover, the production of bulk chemicals from lignin is also a promising process to produce chemicals from biomass, enhancing the environment quality (Figure 3). For unbaked bricks, they have currently been developing in Vietnam to reduce the environmental effect, and these products can also enhance the use of waste materials such as waste lignin from the pulp industry. Dr. Bui from the University of Transport and Communications developed unbaked bricks from inorganic solid waste of the pulp industry ${ }^{34}$. The unbaked bricks synthesized showed an increase in water absorption and a decrease in compressive and yield strengths with an increase in the percentage of the pulp's solid waste (Table 6). Interestingly, the synthesis bricks reached the Vietnam standard TCVN 6477:2016 with the use of 40 and 50\% of the pulp's solid waste. Besides that, the use of $60 \%$ of solid waste was also a promising candidate though having lower yield strength and higher water absorption in comparison to the standard (M150, Table 7). The high amount of using solid waste can be tailored to enhance the physical properties and reduce water 
Table 5: The applications of lignin 25

\begin{tabular}{|c|c|c|}
\hline Seq. & Fields & Application and benefits \\
\hline 1 & Agriculture & $\begin{array}{l}\text { - Lignin-based dispersants, processing aids, and binding agents to the agro- } \\
\text { chemical industry. } \\
\text { - Natural plant nutrition }\end{array}$ \\
\hline 2 & Animal Feed Additives & $\begin{array}{l}\text { - Aquafeed and Fishery } \\
\text { - Pig feeds } \\
\text { - Poultry feeds } \\
\text { - Ruminant feeds }\end{array}$ \\
\hline 3 & Battery Additives & - Organic additives for lead acid batteries \\
\hline 4 & $\begin{array}{l}\text { Carbon Black Disper- } \\
\text { sions }\end{array}$ & - High performance dispersants for aqueous carbon black dispersions \\
\hline 5 & Ceramics & $\begin{array}{l}\text { - Increasing mechanical strength } \\
\text { - Reducing cracks and breakages } \\
\text { - Decreasing energy costs and breakage rates } \\
\text { - Achieving good plasticity with less water } \\
\text { - Reducing final costs }\end{array}$ \\
\hline 6 & Concrete Admixtures & $\begin{array}{l}\text { - Improved strength and durability of the cured concrete } \\
\text { - Reduced formulation cost } \\
\text { - Increased workability of the concrete mix }\end{array}$ \\
\hline 7 & Dyestuff Dispersants & $\begin{array}{l}\text { - Sustainable primary and secondary dispersants for use in disperse, vat, reactive } \\
\text { and acid dyes. }\end{array}$ \\
\hline 8 & Emulsions & - Lignin-derived emulsion stabilisers \\
\hline 9 & Gypsum Board & - Use as water reducers and processing aids in gypsum board manufacturing. \\
\hline 10 & Industrial Binders & $\begin{array}{l}\text { - Sustainable \& environmentally friendly organic binders for the agglomeration } \\
\text { of valuable metallurgical fines }\end{array}$ \\
\hline 11 & $\begin{array}{l}\text { Industrial Cleaners \& } \\
\text { water treatment }\end{array}$ & $\begin{array}{l}\text { - Use as cost-effective additives for industrial cleaning to disperse dirt particles } \\
\text { - Water treatment: formulations to reduce the fouling of cooling water } \\
\text { - A low-cost conditioning agent for boiler water sludges. }\end{array}$ \\
\hline 12 & Oil and gas & - Innovative high-performance solutions for petroleum drilling applications, \\
\hline 13 & Papersizing & $\begin{array}{l}\text { - Green solution for increasing the strength of recycled based corrugated medi- } \\
\text { ums on the size-film press or spray sizer }\end{array}$ \\
\hline 14 & Resin extension & - Extend finished resins or to replace the phenol in such resins fully or partially. \\
\hline 15 & Road \& soil dust control & $\begin{array}{l}\text { - Highly effective dust suppressants for unpaved roads and other areas such as } \\
\text { airstrips, road shoulders, and racetracks, }\end{array}$ \\
\hline
\end{tabular}

Table 6: Compressive and yield strengths and water absorption ${ }^{34}$

\begin{tabular}{cccccccc}
\hline $\begin{array}{c}\text { Name of } \\
\text { prod- } \\
\text { ucts. }\end{array}$ & $\begin{array}{c}\text { Cement } \\
(\%)\end{array}$ & $\begin{array}{c}\text { Ashstone } \\
(\%)\end{array}$ & $\begin{array}{c}\text { Inorganic } \\
\text { waste }(\%)\end{array}$ & $\mathbf{H}_{2} \mathbf{O}(\%)$ & $\begin{array}{c}\text { Compressivi } \\
\text { strength } \\
(\mathbf{M P a})\end{array}$ & $\begin{array}{c}\text { Yield } \\
\text { strength } \\
(\mathbf{M P a})\end{array}$ & $\begin{array}{c}\text { Water } \\
\text { absorption } \\
(\%)\end{array}$ \\
M1 & 10 & 10 & 80 & 15 & 4.26 & 0.66 & 18.50 \\
M2 & 20 & 10 & 70 & 15 & 8.93 & 2.03 & 16.05 \\
M3 & 30 & 10 & 60 & 15 & 15.33 & 2.67 & 12.69 \\
M4 & 40 & 10 & 50 & 15 & 17.80 & 4.70 & 11.26 \\
M5 & 50 & 10 & 40 & 15 & 22.30 & 5.57 & 10.42 \\
\hline
\end{tabular}




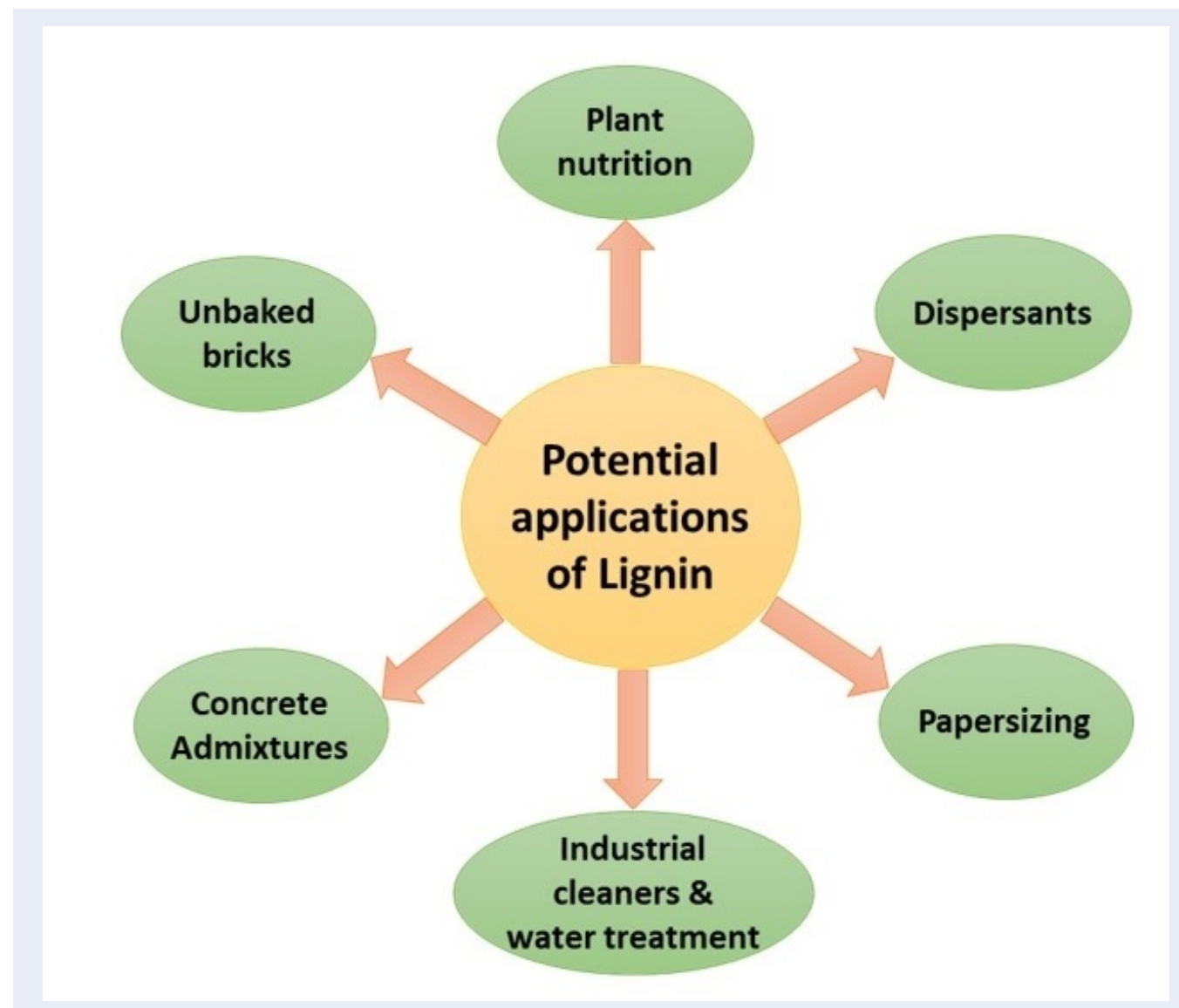

Figure 4: The potential applications of lignin.

Table 7: Compressive and yield strengths, and water absorption of concrete following the TCVN 6477:2016 standard ${ }^{34}$.

\begin{tabular}{cccc}
\hline Standard bricks $(\mathbf{M})$ & $\begin{array}{c}\text { Compressive strength } \\
(\text { MPa })\end{array}$ & Yield strength (MPa) & Water absorption (\%) \\
M35 & 3.5 & - & $<14$ \\
M50 & 5.0 & 1.6 & $<12$ \\
M75 & 7.5 & 1.8 & \\
M100 & 10.0 & 2.2 & \\
M125 & 12.5 & 2.5 & \\
M150 & 15.0 & 2.8 & \\
M200 & 20.0 & 3.4 & \\
\hline
\end{tabular}


absorption to reduce the price of unbaked bricks. As mentioned, lignin can be applied to produce highvalue materials such as carbon fiber precursor and bulk chemicals (Figure 3). Lignin has high advantages in using carbon fibers' precursors due to high carbon yield and negligible toxic through the carbonization process ${ }^{35}$. According to the literature, lignin is the best carbon-fiber precursor ${ }^{35}$. Currently, electrospinning is a promising process to produce carbon nanofibers ${ }^{36,37}$; Lallave et al. ${ }^{36}$ produced carbon fibers with diameters less than $200 \mathrm{~nm}$. Additionally, lignin can be converted into chemicals and fuels through the hydrodeoxygenation (HDO) process $^{38}$. The HDO process transforms lignin into phenolic compounds for surfactants and paint industries, while further HDO process produces hydrocarbons as fuels from lignin. Currently, Hossain et al. ${ }^{39}$ proved that the depolymerization and deoxygenation of the lignin model could be carried out without the addition of hydrogen, opening a new way to develop and produce low-cost chemicals and fuels from lignin.

\section{CONCLUSIONS}

In this work, we summarized and suggested potential products and processes from waste lignin of the pulp and paper industry for the Vietnam market. The industry of lignin is a promising field to enhance the contribution of the wood industry. In parallel, the increase of demand for paper and the investment as well as the good policy of the government, will improve the lignin market and material for further processes. For the Vietnam market, the products from lignin were used for agriculture, construction and basic dispersants are the best to develop due to the low-cost and huge demands. Besides, the development of high-tech materials such as carbon fiber and high valuable raw materials are also considered to gain the industry in Vietnam for the future.

\section{LIST OF ABBREVIATIONS}

BTX: Benzene - Toluene - Xylene

CMT: Corrugating Medium Test

EDTA: Ethylenediaminetetraacetic acid

HDO: the hydrodeoxygenation

NTA: Nitrilotriacetic acid

RCT: Ring Crush Test

SCT: Compression Test

TCVN: the Vietnam standard

\section{COMPETING INTERESTS}

The author(s) declare that they have no competing interests.

\section{ACKNOWLEDGMENT}

This research is funded by the Vietnam National Foundation for Science and Technology Development (NAFOSTED) under grant number 104.05-2019.39.

\section{REFERENCES}

1. Bajwa DS, Pourhashem G, Ullah AH, Bajwa SG. A concise review of current lignin production, applications, products and their environmental impact. Ind Crop Prod. 2019;139:111526. Available from: https://doi.org/10.1016/j.indcrop.2019.111526.

2. Lignin Market Size, Share \& Trends Analysis Report By Product (Ligno-Sulphonates, Kraft, Organosolv), By Application (Macromolecule, Aromatic), By Region, And Segment Forecasts, 2020 - 2027. Grand View Research. 2020;.

3. Haq I, Mazumder P, Kalamdhad AS. Recent advances in removal of lignin from paper industry wastewater and its industrial applications - A review. Bioresour Technol. 2020;312:123636. PMID: 32527619. Available from: https: //doi.org/10.1016/j.biortech.2020.123636.

4. Glasser WG. About Making Lignin Great Again-Some Lessons From the Past. Front Chem. 2019;7(565). PMID: 31555636. Available from: https://doi.org/10.3389/fchem.2019.00565.

5. Hu L, Pan H, Zhou Y, Zhang M. Methods to Improve Lignin's Reactivity as a Phenol Substitute and as Replacement for Other Phenolic Compounds: A Brief Review. Bioresour. 2011;6:3515-3525.

6. Lee S-H, Teramoto Y, Shiraishi N. Resol-type phenolic resin from liquefied phenolated wood and its application to phenolic foam. J Appl Polym Sc. 2002;84(3):468-472. Available from: https://doi.org/10.1002/app.10018.

7. Lora JH, Glasser WG. Recent Industrial Applications of Lignin: A Sustainable Alternative to Nonrenewable Materials. J Polym Environ. 2002;10(1):39-48. Available from: https://doi.org/10. 1023/A:1021070006895.

8. Gosselink R, De Jong E, Guran B, Abächerli A. Co-ordination network for lignin-standardisation, production and applications adapted to market requirements (EUROLIGNIN). Ind Crops Prod. 2004;20(2):121-129. Available from: https://doi. org/10.1016/j.indcrop.2004.04.015.

9. Li C, Zhao X, Wang A, Huber GW, Zhang T. Catalytic Transformation of Lignin for the Production of Chemicals and Fuels. Chem Rev. 2015;115(21):11559-11624. PMID: 26479313. Available from: https://doi.org/10.1021/acs.chemrev.5b00155.

10. Zheng $Y$, Chen D, Zhu X. Aromatic hydrocarbon production by the online catalytic cracking of lignin fast pyrolysis vapors using Mo2N/ $\gamma$-Al2O3. J Anal Appl Pyrol. 2013;104:514-520. Available from: https://doi.org/10.1016/j.jaap.2013.05.018.

11. Berlin A, Balakshin M. Chapter 18 - Industrial Lignins: Analysis, Properties, and Applications. In: Gupta VK, Tuohy MG, Kubicek CP, Saddler J, Xu F, editors. Bioenergy Research: Advances and Applications. Amsterdam: Elsevier. 2014;p. 315336. PMID: 25340264. Available from: https://doi.org/10.1016/ B978-0-444-59561-4.00018-8.

12. Lu Y, Lu YC, Hu HQ, Xie FJ, Wei XY, Fan X. Structural Characterization of Lignin and Its Degradation Products with Spectroscopic Methods. J Spectrosc. 2017;2017:8951658. Available from: https://doi.org/10.1155/2017/8951658.

13. Laurichesse $S$, Avérous L. Chemical modification of lignins: Towards biobased polymers. Progr polymer scl. 2014;39(7):1266-1290. Available from: https://doi.org/10.1016/j.progpolymsci.2013.11.004.

14. Gosselink R, Troosters T, Decramer M. Exercise testing: why, which and how to interpret. Breathe. 2004;1(2):120-129. Available from: https://doi.org/10.1183/18106838.0102.120.

15. Mandlekar N, Cayla A, Rault F, Giraud S, Salaün F, Malucelli $G$, et al. An overview on the use of lignin and its derivatives in fire retardant polymer systems. Lignin-Trends Appl. 2018;207(231). Available from: https://doi.org/10.5772/ intechopen.72963. 
16. Kumar A, Anushree, Kumar J, Bhaskar T. Utilization of lignin: A sustainable and eco-friendly approach. J Energy Inst. 2020;93(1):235-271. Available from: https://doi.org/10.1016/ j.joei.2019.03.005.

17. Securities H. Báo cáo tóm tắt ngành giấy Việt Nam. 2009;

18. Vu THM, Cao DB, Le CH, Le HD. Tổng quan về thực trạng ngành công nghiệp giấy Việt Nam. Khoa học \& Công nghệ. 2019;40:21 -25.

19. Board $\mathrm{E}$. Thị trường giấy và bột giấy Việt Nam: Năm 2019 và nhận định cho năm 2020. Công Nghiệp Giấy. 2020;p. 9-14.

20. Board $E$. Sản xuất và Đầu tư về giáy và bột giấy trên thế giới và Việt Nam năm 2019 - 2020. Công nghiệp Giấy. 2020;p. 15-24.

21. Quyết định Phê duyệt Quy hoạch phát triển ngành công nghiệp Giáy Việt Nam đến năm 2020, có xét đến năm 2025 , 10508/QĐ-BCT. 2014.

22. Linh N. $70 \%$ giấy tại Việt Nam sản xuất từ phế liệu. Vietnambiz. 2018.

23. Minh N. Lee \& Man Việt Nam: 2 năm nỗ lực nâng tầm ngành giấy Việt. Vietnamnetvn. 2020.

24. Paper-Vietnam.Com. Đề xuất xây dựng nhà máy sản xuất bột giấy hơn 11.600 tỷ đồng tại Quảng Trị. Paper-Vietnamcom. 2020.

25. LignoTech. Industrial Applications Borregaard LignoTech: Borregaard LignoTech; [cited 2020 28th April]. 2020;Available from: https://lignotech.com/IndustrialApplications?gclid=Cj0KCQjwhZr1BRCLARIsALjRVQPBPLHt4Pi4dIjWhnZmZYzlajhLh3hcq4JC0WTwM41m9iZn74PzjsaA wcB.

26. Sarkar S, Adhikari B. Thermal stability of lignin-hydroxyterminated polybutadiene copolyurethanes. Polym Degrad Stab. 2001;73(1):169-175. Available from: https://doi.org/10. 1016/S0141-3910(01)00084-2.

27. Pandey MP, Kim CS. Lignin Depolymerization and Conversion: A Review of Thermochemical Methods. Chem Eng Technol. 2011:34(1):29-41. Available from: https://doi.org/10.1002/ ceat.201000270.

28. Barbier J, Charon N, Dupassieux N, Loppinet-Serani A, Mahé L, Ponthus J, et al. Hydrothermal conversion of lignin compounds. A detailed study of fragmentation and condensation reaction pathways. Biomass Bioenergy. 2012;46:479491. Available from: https://doi.org/10.1016/j.biombioe.2012. 07.011.

29. Borregaard. Dyestuff dispersants: lignotech.com; [cited 2020 May 30th]. 2020;Available from: https://lignotech.com/ Industrial-Applications/Dyestuff-Dispersants.
30. Borregaard. Plant nutritioni: lignotech.com; [cited 2020 May 30th]. 2020;Available from: https://lignotech.com/IndustrialApplications/Agriculture/Plant-Nutrition.

31. Borregaard. Concrete admixtures: lignotech.com; [cited 2020 May 30th]. 2020;Available from: https://ignotech.com/ Industrial-Applications/Concrete-Admixtures.

32. Borregaard. Industrial Cleaners \& Water treatment: lignotech.com; [cited 2020 May 30th]. 2020;Available from: https://lignotech.com/Industrial-Applications/IndustrialCleaners-Water-Treatment.

33. Borregaard. Papersizing: lignotech.com; [cited 2020 May 30th]. 2020;Available from: https://lignotech.com/IndustrialApplications/Papersizing.

34. Bui TMA. Nghiên cứu chế tạo gạch không nung từ nguồn chất thải rắn vô cơ trong công nghiệp sản xuất bột giấy và giấy. [cited 2020 28th April]. 2020;Available from: http:// khcncongthuong.vn/tin-tuc/t3533/nghien-cuu-che-tao-gachkhong-nung-tu-nguon-chat-thai-ran-vo-co-trong-congnghiep- san- xuat- bot- giay- va- giay.html?fbclid=IwAR38O_ rjoi3DWzxtD1EeptuhiICdPgrSLMzjPPGGP4C0oCWd2gcl80F-PY.

35. Norgren $M$, Edlund H. Lignin: Recent advances and emerging applications. Curr Opin Colloid Interface Sci. 2014;19(5):409416. Available from: https://doi.org/10.1016/j.cocis.2014.08. 004.

36. Lallave M, Bedia J, Ruiz-Rosas R, Rodríguez-Mirasol J, Cordero AgXfEAL Atero JC, et al. Filled and Hollow Carbon Nanofibers by Coaxial Electrospinning of Alcell Lignin without Binder Polymers. Adv Mater. 2007;19(23):4292-4296. Available from: https://doi.org/10.1002/adma.200700963.

37. Ruiz-Rosas R, Bedia J, Lallave M, Loscertales IG, Barrero A, Rodríguez-Mirasol J, et al. The production of submicron diameter carbon fibers by the electrospinning of lignin. Carbon. 2010;48(3):696-705. Available from: https://doi.org/10.1016/j. carbon.2009.10.014.

38. Shu R, Li R, Lin B, Wang C, Cheng Z, Chen Y. A review on the catalytic hydrodeoxygenation of lignin-derived phenolic compounds and the conversion of raw lignin to hydrocarbon liquid fuels. Biomass Bioenergy. 2020;132:105432. Available from: https://doi.org/10.1016/j.biombioe.2019.105432.

39. Hossain MA, Phung TK, Rahaman MS, Tulaphol S, Jasinski JB, Sathitsuksanoh N. Catalytic cleavage of the $\beta-O-4$ aryl ether bonds of lignin model compounds by $\mathrm{Ru} / \mathrm{C}$ catalyst. Appl Catal A. 2019;582:117100. Available from: https://doi.org/10. 1016/j.apcata.2019.05.034. 